\title{
Analysis User Bus Rapid Transit (Brt) Transportation in Corridor IV as a Solution to Reduce Traffic Congestion in the Sangego, Tangerang City
}

\author{
Kencana Verawati ${ }^{1 *}$, Lu'Luil Maknun ${ }^{1}$, Henita Rahmayanti ${ }^{1}$ \\ ${ }^{I}$ Transportation, Faculty of Engineering State University of Jakarta, Indonesia \\ ${ }^{*}$ Corresponding author.Email: kencanaverawati@unj.ac.id
}

\begin{abstract}
The principle of transportation is to control private vehicles and make public transportation the mainstay of urban travel with public transportation, namely comfortable, affordable fares and a network connecting all parts of the Greater Jakarta city area. With the high mobility of the population in Tangerang City every day, it is hoped that the BRT will be very important in supporting people's daily activities and solutions in preventing traffic jams due to the use of private vehicles. This research aims to determine (1) the performance of roads after the implementation of BRT in Corridor IV Tangerang City (2) the public's preference for changing modes of transportation from private vehicles to BRT (3) BRT user demand forecasting in the next five years. This research aims to calculate the degree of traffic saturation and the distribution of questionnaires to motorized vehicle users in the Sangego area. The results that the degree of saturation $\left(D_{J}\right)$ is less than 0.75 ; on weekdays, the DJ is 0.52 , while on weekends, the degree of saturation is 0.45 ; these results indicate that the traffic flow is stable and the speed of vehicle movement is controlled. The preference for car drivers who can switch to using Bus Rapid Transit (BRT) is 60\% (39 people) and motorcycle riders 79\% (67 people). Forecasting BRT users from 2021-2025 will increase by 5-6\% per year.
\end{abstract}

Keywords: BRT Transportation, Traffic congestion, BRT Forecasting, Traffic Saturation

\section{INTRODUCTION}

The principle of the urban transportation system is to deal with environmental, social and economic aspects, namely to restrain the use of urban private cars and make public transportation the mainstay of the journey of the urban population. The application of this principle aims to increase the mobility of urban residents due to the availability of public transportation, convenient transportation, affordable fares and a network that can connect all parts of the city area. Therefore, the availability of mass or public transit must meet travel needs so that people are willing to switch from private or private vehicles to public transit [1].

The Tangerang City Transportation Service, as one of the regional apparatus organizations, which is involved in the implementation and management of traffic, its main duties and functions are regulated in Regional Regulation Number 8 of 2016 concerning the Formation and Composition of Regional Apparatuses, specifically held further through the Regulations Office Mayor
Number 64 of 2018 concerning the establishment of the Organization and Work Procedure of the Technical Implementation Unit for the Management of Transportation Infrastructure at the Transportation Service.

The Tangerang City Transportation Service has several roles, including organizing government affairs and public services, especially in transportation. The Tangerang City Transportation Service has four fields and three technical implementing units, including the Transportation System Development Sector, the Transportation Sector, the Traffic Sector, the Public Street Lighting Sector, the Mass Public Transport Regional Technical Implementation Unit, the Regional Technical Implementation Unit for Motor Vehicle Testing and the Regional Technical Implementation Unit Terminal.

As a form of responsibility for the Tangerang City government in meeting the needs for mass public transportation for the community, BRT (Bus Rapid 
Transit) is currently divided into 4 (four) corridors. BRT is one of the results of developments in the transportation technology sector of road-based mass public transport modes. The definition of Bus Rapid Transit (BRT), according to the BRT Standard (2015) in the BRT Planning Guideline [2] is a bus-based rapid public transport system that can reach high capacity and speed at a relatively lower cost by combining bus lines that which are generally parallel to the road median, off-board fare collection, boarding platforms similar to the bus floor, bus priority at intersections, as well as other other services quality elements such as the implementation of information technology and branding.

According to [3] that the use of public transportation performance, both city buses, inner-city transportation, and BRT, is currently still below $80 \%$. This means that urban public transportation is relatively not an option for some people in Tangerang City. From the results of the transportation performance survey that has been carried out on the types of city bus transportation, urban transportation and BRT corridors I and II serving in the Tangerang City area, City Buses have an average load factor of $60.22 \%$, urban transportation of $31.93 \%$, and BRT by $39.5 \%$.

In the short term, the Bus Rapid Transit (BRT) system aims to move large numbers of passengers in a relatively short period and those who make various types of urban transportation trips. Meanwhile, in the long term, the implementation of Bus Rapid Transit (BRT) aims to provide cheap transportation services to low-income residents, encourage job opportunities, and support the growth of transportation-friendly cities. One of the current general policies of transportation development is sustainable transportation through integrated mass public transportation, where BRT mass public transportation, including its feeder transportation, is the main key in answering transportation problems in every city in Indonesia [4].

The presence of BRT with its various facilities is expected to fulfil the mandate of Law No. 22 of 2009 concerning Road Traffic and Transportation. Regulation of Minister of Transportation of the Republic of Indonesia Number PM 15 of 2019 concerning the Implementation of Transportation of People with Public Motorized Vehicles on the Route, and Regulation of the Regent of Tangerang Number 77 of 2019 concerning the Implementation of Transportation of People with Public Motorized Vehicles on the Route. The Regional Technical Implementation Unit for Mass Public Transportation of the Tangerang City Transportation Service was appointed to be one of the parties to ensure the availability of mass public transportation.
Ownership of private vehicles results in a person's tendency not to use public transportation. This also causes involvement in socio-cultural which is less supportive for the community in manifesting justice in transportation which can improve transportation, accessibility, and increase social exclusivity in society [5].The decrease in the volume of use of public transportation makes operators have to find new ways to regain public trust. Public transport operators should focus on making public transport capable and finding safer ways to fly [6].

As one of the buffer cities or satellite cities of the Capital City of DKI Jakarta, Tangerang City, where the demand for industrial growth and trade in services and commerce is getting higher, it also puts significant pressure on the rate of population growth. As a progressing city, of course, like other big cities, Tangerang City has several urban problems. One of the things is the problem of traffic jams so that it is necessary to organize and manage traffic and public transportation well. The increasing use of private vehicles shows that people's dependence on private vehicles is still high. This is because the existing public transportation is not yet comfortable, safe and fast, so people prefer to use private vehicles as their mode of travel. Transportation is a process of moving from the place of departure to the destination to achieve a certain goal; with the development of transportation sector facilities and infrastructure, it is certainly very easy for the people's daily activities [7].

The Tangerang City BRT has 4 corridors including: (1) Poris Plawad Terminal - Jatiuwung-Jatake GOR (2) Poris Plawad Terminal - Cibodas Terminal (3) CBD Ciledug - Tangcity and (4) Periuk Jaya - Soekarno-Hatta International Airport. Corridor IV has just opened for passenger transportation operations in January 2021, which is expected to reduce traffic congestion as people switch to public transportation. BRT Corridor IV is made as good as possible for services to BRT users, including television facilities, chairs made of foam or like a sofa. In addition, the interior of the BRT Corridor IV is more friendly for elderly passengers.

The congestion in Tangerang City, especially the Sangego area, which will become the corridor IV BRT route, will affect the community's productivity in general because the road is a supporting infrastructure for a movement that helps interaction between activities in the form of goods and people. For this reason, a solution is needed to overcome these problems, one of which is to use mass transportation that is comfortable, safe and fast so that private vehicle users who have been burdening roads can switch to using mass transportation. The systems approach to transportation planning is an attempt 
at engineering by analyzing all the factors related to the problems. The system approach will question the current issues by unravelling all the causal factors. Solutions to the problem can be in local traffic system management, improvement of public transport services, construction of new road infrastructure or new land-use planning. An example of problem-solving is traffic management; this system approach tries to produce the best alternative solution with all existing constraints (time and cost) [8].

According to [9] research on Public Transport in South Tangerang City, it shows that consumer behaviour in choosing to use public transportation is influenced by service quality, the perceived value has a positive mediating effect on service quality and perceived value on consumer behaviour in the people of South Tangerang City.

In anticipation of the existence of movement activities, we need a transportation design arranged in the transportation network system. One part of the work that is the authority and responsibility of the autonomous region is implementing regional transportation schemes that are following the region's needs. The importance of organizing this transportation will be seen by the increasing demand for mobility for transportation services. The Tangerang City Government, in this case through the Transportation Service, which is a related regional instrument work unit that has the main task and function in the field of traffic regulation and control in Tangerang City, one form of anticipation carried out by the Tangerang City Transportation Service in dealing with congestion or overcrowding problems. Use of private vehicles and form a transportation network for the City of Tangerang.

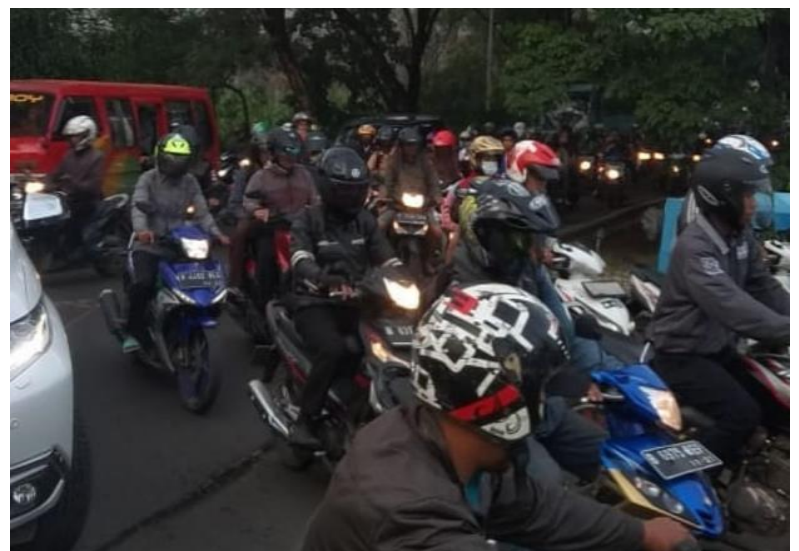

Figure 1. Situation of Heavy Traffic Flow from Sangego Direction.

The Public transport is an investment that can create jobs quickly while reducing carbon emissions to the environment, making roads safer from accidents and increasing people's access to places where their activities are intended, such as workplaces and other opportunities [10]. Public transportation is very important and becomes a means used by the community for activities such as work, school, etc. The existence of corridor IV BRT is very meaningful; to support this, a demand analysis is needed to balance the demand and availability of BRT in corridor IV.

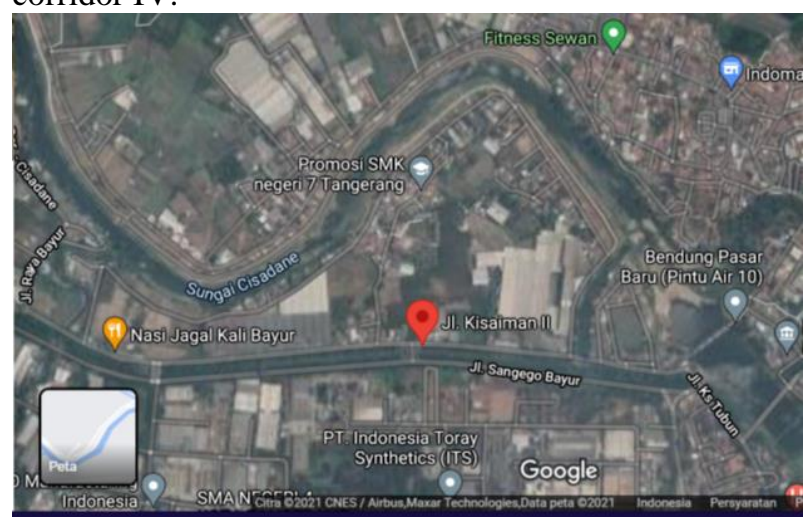

Figure 2. Sangego Area, Tangerang City.

High mobility causes problems such as traffic jams. This is due to the increasing volume of private vehicle use that is not accompanied by infrastructure development. According to the Number of Motorized Vehicles from data from the Central Statistics Agency of Banten Province, Tangerang City, motorcycles increased by $7-8 \%$ per year and vehicles increased by $5-16 \%$ per year. If there is no effort to improve, Tangerang City will experience total congestion.

Congestion due to the accumulation of private vehicles has occurred on Sangego area, one of the roads or areas supporting mobility to Soekarno Hatta Airport and Jakarta City. This causes the accumulation of vehicles or congestion around the area, especially during peak hours.

Table 1. Degree of Saturation $\left(D_{j}\right)$ in 2020

\begin{tabular}{|c|c|c|}
\hline $\begin{array}{c}\text { Volume } \\
\text { (skr/hour) }\end{array}$ & $\begin{array}{c}\text { Capacity } \\
\text { (skr/hour) }\end{array}$ & $\begin{array}{c}\text { Volume/Capac- } \\
\text { ity }\end{array}$ \\
\hline 2,311 & 2,702 & 0.85 \\
\hline
\end{tabular}

The density of private vehicles on Sangego area also causes a buildup of vehicles or congestion around the area; data from the Tangerang City Transportation Service, the volume capacity ratio in 2020 in the area around Sangego is at 0.85 , which indicates that the traffic characteristics in the area are traffic flow. Unstable, speed sometimes stalls and demand is approaching capacity. So in dealing with congestion problems and 
Table 2. Traffic survey data

\begin{tabular}{|c|c|c|c|}
\hline \multirow{2}{*}{ Day } & Survey Time $(\mathrm{WIT})$ & Light Vehicles (KR) & Motorcycles (SM) \\
\hline \multirow{3}{*}{ Friday } & $16: 30-16: 45$ & 176 & 443 \\
\cline { 2 - 4 } & $16: 45-17: 00$ & 155 & 432 \\
\cline { 2 - 4 } & $17: 00-17: 15$ & 148 & 591 \\
\cline { 2 - 4 } & $17: 15-17: 30$ & 143 & 377 \\
\hline \multirow{3}{*}{ Monday } & $16: 30-16: 45$ & 82 & 311 \\
\cline { 2 - 4 } & $16: 45-17: 00$ & 130 & 343 \\
\cline { 2 - 4 } & $17: 00-17: 15$ & 151 & 388 \\
\cline { 2 - 4 } & $17: 15-17: 30$ & 154 & 516 \\
\hline
\end{tabular}

considering the application of traffic engineering, one of the policies taken is the application of Bus Rapid Transit (BRT), namely as a means of mass public transportation for the people of Tangerang City, which until 2021 has been launched 4 (four) bus corridor, the newest corridor is corridor IV (four) serving the Simpang Selapajang Simpang Nagrak route which began operating on January 2021.

Jabodetabek (Jakarta, Bogor, Depok, Tangerang and Bekasi) area is an area in Indonesia with a large population, so there is a very high number of transportation movements. It is due to the increased activity and meetings [11]. The purpose of this research is to discuss the use of BRT as a solution to congestion in Tangerang City by observing the absorption capacity of the operation of Tangerang City BRT, which is one of the areas traversed by Bus Rapid Transit (BRT), precisely in corridor IV (four) - seeing that public transportation or mass transportation has an important role in transportation-from this description, knowing (1) the performance of the road after the implementation of BRT in Corridor IV Tangerang City (2) the public's preference for changing transportation modes from private vehicles to BRT (3) BRT user demand forecasting in five years (2021-2025).

\section{METHODS}

The research method used in this research is a quantitative technique. The quantitative method is a research method intended to provide information on the conditions of BRT use in Corridor IV by the community, which will directly reduce congestion in the Tangerang area. Quantitative methods, which mostly use deductive reasoning, seek to find order in human life by separating the social world into empirical segments called variables. The purpose of quantitative research is to find relationships between variables or to compare certain samples or groups related to research results. In general, a research with quantitative methods emphasizes the breadth of information (not depth); therefore, this method is suitable for use in large populations with limited variables.

This research includes field research, which describes and describes the situation and phenomena more clearly regarding the situation that occurred. This research on the traffic analysis process consists of calculating traffic volume on Sangego area, where a traffic survey has been carried out for two days, which includes representative days, namely Friday and Sunday. Observations and surveys of traffic flow were carried out in the afternoon at 16:30-18:30 WIT (Western Indonesian Time), which was the deadline for ending activities in a day, which is one of the peak hours. The number of passing vehicles was recorded on the survey sheet for 15 minutes. Traffic observation and survey data can be seen in Table 2 .

\section{RESULTS AND DISCUSSION}

Analysis of the existing road performance is the calculation of the actual conditions in the road segment being reviewed; this analysis is used to evaluate traffic performance, including traffic flow with the hours that exist at a certain time when evaluated. This research and survey were conducted on Street Sangego, Tangerang City, during the afternoon rush hour, the hour is interpreted to be one of the times, where the traffic flow becomes high in a day. The data from the traffic survey conducted is processed in traffic flow (Q) and can then be used to calculate the saturation level $\left(D_{\mathrm{J}}\right)$.

The data in table 2 is needed to determine the sample clearance of the questionnaire to determine the community's choice of using private transportation to public transportation (BRT). The population with the highest number of motorcycle (SM) users in the 15-minute observation was 591 units. The highest number of confidential car (KR) users in the 15-minute statement was 176 
Table 3. Estimated Capacity of the Sangego Area

\begin{tabular}{|l|c|c|c|}
\hline \multicolumn{2}{|c|}{ Parameter } & Condition & Value \\
\hline Base capacity (cur/hour) & $\mathrm{c}_{0}$ & $2 / 1 \mathrm{t}$ & 3300 \\
\hline Lane or lane width adaptation factor & fc $_{\mathrm{lj}}$ & $3 \mathrm{~m}$ & 0,92 \\
\hline Directional separation adaptation factor & $\mathrm{fc}_{\mathrm{pa}}$ & $50 \%-50 \%$ & 1 \\
\hline Side resistance adaptation factor & $\mathrm{fc}_{\mathrm{hs}}$ & sedang & 0,89 \\
\hline City size adaptation factor & $\mathrm{fc}_{\mathrm{uk}}$ & 2273697 & 1 \\
\hline \multicolumn{2}{|r|}{ Actual road segment capacity (skr/hour) } & 2702 \\
\hline
\end{tabular}

units, so the number of samples collected from the population using the solving method with an error tolerance level of $10 \%$ was 150 questionnaires, which will be deployed in the Sangego Area, Tangerang City. Determination of the sample using the Slovin formula obtained 65 private cars and 85 private motorcycles.

$$
n=\frac{N}{1+N e^{2}}
$$

Information :

$\mathrm{N}=$ Population

$\mathrm{n}=$ Sample

$\mathrm{e}=$ Level of leniency in sampling (error tolerance)

The tangerang city bus rapid transit (brt) or trans tangerang is a regional public transportation system extended to the main corridor, as a branch of other public transportation routes or as a feeder for other mass, for example, transjabodetabek and rail transportation. the service model on the trans tangerang brt is guided by the minimum service standards (spm), which have been adjusted, among others, by providing safer, regularly scheduled, affordable, convenient and comprehensive services for public passengers in the tangerang area. trans tangerang buses in normal conditions start functioning from 05:00 to 21:00 wit.

The Tangerang City Bus Rapid Transit (BRT) public transportation system started running for the first time on December $1^{\text {st }}, 2016$, to reduce congestion problems and provide mass public transportation that can provide a comfortable, safe, clean and fast feeling. The payment process applied is the non-cash method of the Electronic Data Capture (EDC) system that can accept non-cash money from various applications for electronic wallet service providers.

\subsection{Degree of Saturation (Dj)}

\subsubsection{Road segment capacity (c).}

In calculating the capacity of the road segment, it is influenced by the condition of the geometric characteristics of the road (road type, traffic, kerb, lane width, road shoulder, and road median), the composition of the flow and direction separator, the population of the city, and activities or the presence of roadside obstacles. this calculation is obtained from observing the required data on sangego tangerang city, including the following; 1. road type: $2 / 1 \mathrm{tt}$ ( 2 lanes one way undivided)

2. road width: $6 \mathrm{~m}$

3. separation direction: $50-50$

4. side disorders: moderate

5. total population : 2,273,697 people

\subsubsection{Traffic Flow $(Q)$.}

Based on the data from the results of direct observations of traffic that have been made, before the data is processed for calculations in the next analysis, first the information needs to be converted into light vehicle units (skr) per hour, the conversion is done using multiplication between the number of vehicles for one hour multiplied by the light vehicle equivalence value (ekr).

\subsubsection{Determination of Peak Hours and Total Traffic Flow}

After knowing the value of the light vehicle equivalence (ekr) in the next cur/hour, it is to determine the peak hour per direction for 2 hours of carrying out the traffic survey.

Table 4. Total Flow on Friday (16:30-17:30 WIT)

\begin{tabular}{|c|c|c|c|c|}
\hline No & Time (WIT) & MP & $\mathrm{KB}$ & SM \\
\hline 1 & $16: 30-16: 45$ & 176 & 15 & 443 \\
\hline 2 & $16: 45-17: 00$ & 155 & 14 & 432 \\
\hline 3 & $17: 00-17: 15$ & 148 & 14 & 591 \\
\hline 4 & $17: 15-17: 30$ & 143 & 9 & 377 \\
\hline \multicolumn{2}{|c|}{ Total (vehicle/hour) } & 622 & 52 & 1,843 \\
\hline & Ekr & 1 & 1.3 & 0.4 \\
\hline \multicolumn{2}{|c|}{ Total (skr/hour) } & 622 & 67.6 & 737.2 \\
\hline \multicolumn{2}{|c|}{ Traffic flow Q (skr/hour) } & & \multicolumn{2}{|c|}{1,427} \\
\hline
\end{tabular}


Table 5.Total Flow on Sunday (16:30-17:30 WIT)

\begin{tabular}{|c|c|c|c|c|}
\hline No & Time (WIT) & MP & $\mathrm{KB}$ & SM \\
\hline 1 & $16: 30-16: 45$ & 82 & 10 & 311 \\
\hline 2 & $16: 45-17: 00$ & 130 & 18 & 343 \\
\hline 3 & $17: 00-17: 15$ & 151 & 15 & 388 \\
\hline 4 & $17: 15-17: 30$ & 154 & 12 & 516 \\
\hline \multicolumn{2}{|c|}{ Total (vehicle/hour) } & 517 & 55 & 1,558 \\
\hline \multicolumn{2}{|l|}{ Ekr } & 1 & 1.3 & 0.4 \\
\hline \multicolumn{2}{|c|}{ Total (skr/hour) } & 517 & 71.5 & 623.2 \\
\hline \multicolumn{2}{|c|}{ Traffic flow Q (skr/hour) } & \multicolumn{3}{|c|}{1,212} \\
\hline
\end{tabular}

Based on table 5, the overall value in two hours of observation, namely at 16:30 - 17:30 WIT through the number of MP, KB and SM motorized transportation as the calculation of traffic flow (Q) is 1,212 skr/hour.

Degree of saturation level $\left(D_{J}\right)$ is calculated using the following equation:

$$
\text { Dj } \frac{Q}{C}
$$

$\mathrm{D}_{\mathrm{j}}=$ Degree of saturation

$\mathrm{Q}=$ Traffic flow (skr/hour)

$\mathrm{C}=$ Road capacity (skr/hour)

The following is the creation of an existing DJ on Sangego on weekdays and weekends (Table 4 and 5).

Weekdays

Weekend

$$
D j=\frac{1,427}{2,702}=0.52
$$

$$
D j=\frac{1,212}{2,702}=0.45
$$

\subsection{Respondents Willingness to Switch to BRT}

The results of the questionnaire processing were obtained as many as 65 respondents to the questionnaire using private car users who were willing to switch to using Bus Rapid Transit (BRT) as many as 39 people $(60 \%)$, and $26(40 \%)$ respondents who were not willing to switch. Meanwhile, it was found that from 85 respondents to the questionnaire, motorcycle riders who were ready to move using Bus Rapid Transit (BRT) were 67 people (79\%) respondents, and $18(21 \%)$ were not willing to move.
Table 6. Respondents Willingness to Switch to BRT

\begin{tabular}{|c|c|c|c|c|c|}
\hline \multirow{2}{*}{ No. } & \multirow{2}{*}{ Remark } & \multicolumn{3}{|c|}{ Car } & \multicolumn{2}{c|}{ Motorcycle } \\
\cline { 3 - 6 } & & $\begin{array}{c}\text { Frequency } \\
\text { (Units) }\end{array}$ & $\%$ & $\begin{array}{c}\text { Frequency } \\
\text { (Units) }\end{array}$ & $\%$ \\
\hline 1 & Yes & 39 & $60 \%$ & 67 & $79 \%$ \\
\hline 2 & No & 26 & $40 \%$ & 18 & $21 \%$ \\
\hline
\end{tabular}

\subsection{Request for Bus Rapid Transit (BRT) Pas- senger Data}

\subsubsection{Data on Population Growth in Tangerang} City.

Population data obtained from the Central Bureau of Statistics of Tangerang City is seen in table 7. The GRDP (Gross Regional Domestic Product) data in this research is used to obtain regional per capita income values. The table below will show the GRDP data for the city of Tangerang in 2016-2020 is 5.86\%. To predict the number of public transport passengers in the next 5 years (20212026) the demographic growth model of Tangerang City has an average population growth of $2.08 \%$ per year. Based on a survey conducted on the Sangego area, the number of public transportation for 1 hour is 160 people on weekdays and 130 people on weekends.

Calculation of demand for Bus Rapid Transit (BRT) users contained in this research, all users of city transportation (urban transportation) are assumed to switch to using Bus Rapid Transit (BRT). Many urban transportation users and private vehicle mode are obtained from traffic survey observations in the field.

Table 7. Data on Population Growth in Tangerang City

\begin{tabular}{|c|c|c|}
\hline Year & Total Population & Growth (\%) \\
\hline 2016 & $2,093,706$ & - \\
\hline 2017 & $2,139,891$ & 2.20 \\
\hline 2018 & $2,185,304$ & 2.12 \\
\hline 2019 & $2,229,901$ & 2.04 \\
\hline 2020 & $2,273,697$ & 1.96 \\
\hline & Growth Rate & 2.08 \\
\hline
\end{tabular}

In estimating the demand for prospective Bus Rapid Transit (BRT) passengers, this research uses the approach that the future growth of city transportation passengers (urban transportation) is directly proportional to the increase in population, such a calculation of passenger growth every year can use the demographic growth percentage of Tangerang City. Similarly, in predicting private vehicle users who are willing to switch to using 
BRT, the percentage growth in per capita income is due to a person's capacity to own a vehicle according to the amount of income. After getting the number of city transportation users and the number of private vehicle users who want to switch to using Bus Rapid Transit (BRT).

$$
\text { Demand }=(A u \times 100 \%)+(M P \times a \%)+
$$
(SM $\times b \%)$

Information:

$\mathrm{Au}=$ Number of city transportation passengers (urban transportation-field survey)

MP = Number of private car passengers per hour (cur/hour)

$\mathrm{SM}=$ Number of motorcycle passengers per hour (cur/hour)

$\mathrm{a}=$ Percentage of private car drivers who are willing to switch to BRT (\%)

$\mathrm{b}=$ Percentage of motorcycle riders who are willing to switch to BRT (\%)

With the interpretation that one mode of a private vehicle is also driven by one person, for SM and MP values on weekdays and weekends using third formula. An example of calculating BRT user demand in 2021.

1.Weekday (Friday)

Number of car passengers $(\mathrm{MP})=622$ people

Number of motorcycle passengers $(\mathrm{SM})=1,843$ people

Demand BRT on Weekday

$=(160)+(373)+(1,455)$

$=1,988$ people/hour

2.Weekend (Sunday)

Number of car passengers $(\mathrm{MP})=517$ people

Number of motorcycle passengers $(\mathrm{SM})=1,558$ people Demand BRT on Weekend

$=(130)+(310)+(1,230)$

$=1,670$ people/hour

Meanwhile, the percentage of switching to private vehicle users was obtained from questionnaire data processing, with the result that the rate of car drivers who were willing to change was written with 'a' amounting to $60 \%$ and motorcycle riders who were willing to switch written 'b' amounted to $79 \%$.

Table 8. Forecasting Demand Bus Rapid Transit (BRT) on Weekday

\begin{tabular}{|c|c|c|c|c|}
\hline Year & $\mathrm{Au}$ & $\mathrm{MP}$ & $\mathrm{SM}$ & Demand \\
\hline 2021 & 160 & 373 & 1,455 & 1,988 \\
\hline 2022 & 163 & 395 & 1,540 & 2,098 \\
\hline 2023 & 166 & 418 & 1,630 & 2,214 \\
\hline 2024 & 171 & 442 & 1,725 & 2,336 \\
\hline 2025 & 175 & 468 & 1,826 & 2,467 \\
\hline
\end{tabular}

Table 9. Forecasting Demand Bus Rapid Transit (BRT) on Weekend

\begin{tabular}{|c|c|c|c|c|}
\hline Year & $\mathrm{Au}$ & $\mathrm{MP}$ & $\mathrm{SM}$ & Demand \\
\hline 2021 & 130 & 310 & 1,230 & 1,670 \\
\hline 2022 & 133 & 328 & 1,302 & 1,763 \\
\hline 2023 & 136 & 347 & 1,378 & 1,861 \\
\hline 2024 & 139 & 367 & 1,458 & 1,964 \\
\hline 2025 & 142 & 388 & 1,540 & 2,070 \\
\hline
\end{tabular}

The calculation of the forecasting value for the $\mathrm{Au}$ value is obtained by multiplying the value of the number of city transportation passengers (urban transportation) and the average percentage of population growth of $2.08 \%$. At the same time, the calculation for the value of MP (Private Car) and SM (Motorcycle) is by multiplying the value of the number of passengers in cur/hour and the percentage of income per capita of $5.86 \%$. In calculating the demand for prospective passengers, namely, adding up the Au value, MP value, and SM value.

\section{CONCLUSION}

The important conclusion from the above research are as follows:

Analysis of the performance level of roads in the Sangego area in the form of degrees of saturation after the operation of BRT Corridor IV, from the results of observations and traffic surveys on the existing road segment, namely Sangego area for two days of the word, the DJ value is obtained which is a parameter of road performance level. The DJ value obtained on weekdays is 0.52 while on weekends it is 0.45 , which means that the level of road service is less than $0.75(<0.75)$; this situation indicates that traffic flow on Sangego area after the BRT Corridor IV is classified as a stable level and the vehicle's movement speed is still under control.

Identification of preferences for the choice of transportation modes by the community. Based on the results of data processing from the distribution of questionnaires, it is found that the percentage of private car drivers who are willing to switch to using Bus Rapid Transit (BRT) is 60\%. The percentage of motorcycle riders willing to switch to using Bus Rapid Transit (BRT) is $79 \%$.

In the analysis of demand data for prospective Bus Rapid Transit (BRT) passengers in the City That in the calculation of forecasting predictions for BRT users from 2021-2025 will increase by 5-6\% per year.

It is expected that the present research will be highly useful for researchers and transportation practitioners to understand and conduct further research in public transportation in overcoming congestion in urban areas. 


\section{REFERENCES}

[1] Y Chrisnawati, S Nurhana, A Pendahuluan, H. Auri, and B. M. Penelitian, 'Analisis Kerja Operasional Transjakarta Koridor 2 Tanah Abang Explorer dalam Upaya Peningkatan Pelayanan', vol. XII, no. 1, pp. 21-25, 2019.

[2] L Wright and H Walter, 'The BRT Planning Guide', Itdp, p. 1076, 2017.

[3] E Dianawati, P P Yanti, and Y Suryandari, 'Klustering Jumlah Penumpang pada Halte Bus Rapid Transit Kota Tangerang', J. Sist. Cerdas, vol. 2, no. 3, pp. 163-172, 2019, doi: 10.37396/jsc.v2i3.34.

[4]W A Riawan, 'Analisis Pelayanan Bus Rapid Transit Kapasitas Sedang pada Sistem Transportasi Perkotaan [The Service Analysis of Medium Capacity Bus Rapid Transit on the Urban Transportation System]', War. Penelit. Perhub., vol. 30, no. 2, pp. 119-132, 2018, doi: 10.25104/warlit.v30i2.688.

[5] P Bucsky, 'Modal share changes due to COVID-19: The case of Budapest', Transp. Res. Interdiscip. Perspect., vol. 8, 2020, doi: 10.1016/j.trip.2020.100141.

[6] J De Vos, 'The effect of COVID-19 and subsequent social distancing on travel behavior', Transp. Res. Interdiscip. Perspect., vol. 5, no. May, p. 100121, 2020, doi: 10.1016/j.trip.2020.100121.

[7] D Suyadi and R Imaulanda, 'Analisis Tingkat Pelayanan Jalan Menggunakan Perangkat Lunak Vissim Pada Simpang Bersinyal Cisalak, Kota Depok', Logistik, vol. 12, no. 2, pp. 1-3, 2019, doi: 10.21009/logistik.v12i2.17604.

[8] T K A Putra and A S Kurnia, 'Analisis Preferensi Masyarakat Terhadap Bus Rapid Transit (BRT) Trans Semarang', Diponegoro J. Econ., vol. 3, no. 1, pp. 1-15, 2014.

[9] NANI and S F Almassawa, 'Perilaku Pengguna Angkutan Umum Perkotaan di Tangerang Selatan', J. Manaj. Transp. Logistik, vol. 06, no. August, pp. 1-10, 2019.

[10] B Welle and S Avelleda, 'Safer, More Sustainable Transport in a Post-COVID-19 World', World Resour. Inst., pp. 1-7, 2020.

[11] S A Azwar and Y Abdurrohman, 'Pengaruh Pandemik Covid-19 Terhadap Gerakan Transportasi Di Jabodetabek the Influence of Pandemic Covid-19 on Transportation Movement in Jabodetabek', vol. 14, no. 01, pp. 27-36, 2021. 